\title{
Functional Tolerance of the Cervical Cord in Giant Ependymoma
}

\section{Hernando Rafael}

Neurosurgeon, Clínica Santa Monica, Lima, Peru

*Corresponding author: Hernando Rafael, Belgica 411-BIS Colonia Portales, 03300 Mexico City, Mexico, Tel: +5255 5532 9101; Fax: 51991489 111; E-mail: hrtumi@yahoo.com

Rec date: Jan 28, 2016; Acc date: Mar 29, 2016; Pub date: Jun 11, 2016

Copyright: $\odot 2016$ Rafael $\mathrm{H}$. This is an open-access article distributed under the terms of the Creative Commons Attribution License, which permits unrestricted use, distribution, and reproduction in any medium, provided the original author and source are credited.

\begin{abstract}
Author reports to a 42-year-old man who suffered motor impairment in his limbs since 17-years of age, and five years later he presented central pain. In August 2011, a preoperative MRI scans showed syringobulbia and a giant intramedullary tumor, which occupied $70 \%$ of the cervical cord. The neoplasm was surgically removed and the histological study was recognized as cellular ependymoma. At present, 56 months after surgery the patient can walk with or without assistance and persists with central pain. This patient confirms previous observations that in dyscomplete transection there are axons in function and that could improve after a decompression or revascularization. Moreover, this patient confirms that there is a huge tolerance of the spinal cord to chronic injuries.
\end{abstract}

Keywords: Central pain; Cervical cord; Syringobulbia syringomyelia; Ependymoma

\section{Introduction}

Primary spinal cord tumors constitute 20 percent and 35 percent of all intraspinal tumors (intramedullary, intradural extramedullary and extradural) in adults and children respectively [1,2]. Spinal ependymomas are the most common intramedullary spinal cord neoplasm in adults comprising $60 \%$ of all glial spinal cord tumors $[3,4]$.

I present to a patient with syringobulbia, syringomyelia and intramedullary ependymoma located in the cervical and upper thoracic cord whose initial symptoms were slight motor impairment and central pain in his limbs.

\section{Case Report}

This 42-year-old man had a history of syringomyelia and intramedullary ependymoma located in the cervical and upper thoracic cord. Since 17-years of age, he began with motor impairment in upper and lower limbs. These symptoms were little frequents during weeks and/or months. Five years later, he presented articular pain in hands, as well as tactile hypersensitivity in upper limbs and burning pain in the left side of the chin and face. About 30 years of age, he manifested pain as aching, numbness or burning in arms, thighs, hands and feet. In the last seven years, he presented moderate pain in the neck, shoulders, deep pain in the thorax and the burning pain in the extremities was almost constant. A year before his admission, he began walking with staggering gait.

\section{Examination}

The patient came to a local hospital walking without assistance His voice and swallowing were normal. He presented hypotonic brachial diparesis (grade 4), spastic paraparesis (grade 4-5), patellar hyperreflexia and clonus at the ankles, Babinski's sign on the right foot. The superficial and deep sensory were almost normal, except tactile hypersensitivity in arms. He never suffered bladder or rectal disorders. A preoperative Magnetic Resonance Imaging (MRI) scans
(August, 2011) showed syringobulbia and well-defined intramedullary tumor involvement ranged from $\mathrm{C} 2$ to $\mathrm{T} 5$ level (Figures $1 \mathrm{~A}$ and $1 \mathrm{~B}$ ) and occupying $70 \%$ of transverse diameter in the cervical cord (at the C4-C6 level). Before surgery, the extirpation of the tumor was proposed to the patient and his family. This preoperative picture was recorded on videotape.

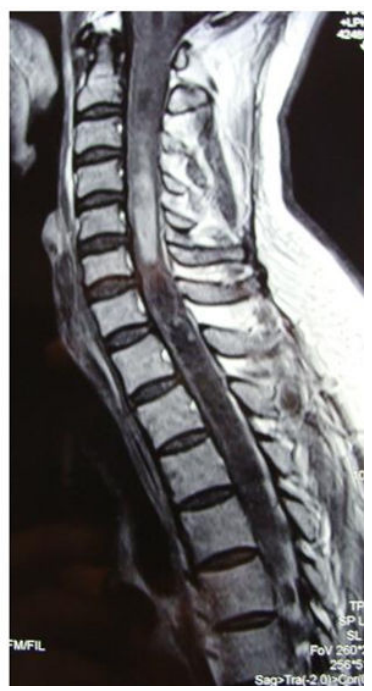

Figure 1A: Preoperative Sagittal T1 MRI with contrast showing syringobulbia, and solid ependymoma ( $\mathrm{C} 4$ to $\mathrm{C} 6$ ) and Soft ependymoma (C6 to T5).

\section{Operation}

With the diagnosis of intramedullary neoplasm in the cervical and upper thoracic cord, he was operated on September 2011 in the Hospital National Guillermo Almenera Irigoyen (Lima, Peru). Through a left hemi-laminectomy at the T3 - T6 level, the neoplasm was removed. The tumor was surgically extirpated under microscope 
magnification, and dissected following plane of cleavage between tumor and spinal cord tissue. The histological study of the tumor was recognized as cellular ependymoma.

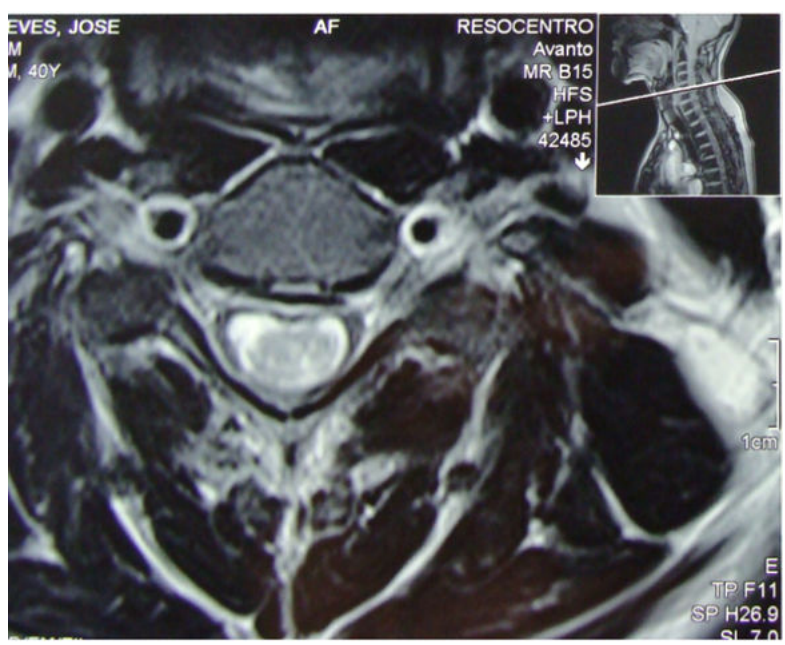

Figure 1B: Preoperative Axial T2 MRI Showing solid ependymoma, which represents about 70 percent of cross-sectional area of the cervical cord (between C4-C5).

\section{Postoperative course}

On the first postoperative days he presented hypotonic tetraparesis (grade 1-2) and burning pain in the limbs, as well as loss in the control of both sphincters. Neurological improvement was observed after 30 days of the operation and it was slow and progressive. He received rehabilitation and radiotherapy in the cervical and upper thoracic cord. A postoperative MRI scans (March, 2013) revealed severe hypotrophy of the cervical and thoracic cord, especially from C2 to T5 (Figure 2) and he presented, brachial diparesis (grade 3-4) and spastic paraparesis (grade 3-5). He walked with aid of a cane. This postoperative picture was recorded on videotape.

At present, 56 months after surgery, the motor evaluations in the upper and lower limbs are of grade 3-5. He can walk with assistance or aid of a cane. Throughout the postoperative course, he suffers of moderate to severe central pain (continuous pain, burning pricking, shining or pricks) in limbs and chest His sensory bladder and rectal function is almost normal. He receives pregabalin as treatment for the central pain.

\section{Discussion}

This patient confirms that the spinal cord has a great tolerance to chronic injury and by contrast, it can experience functional recovery after decompression or revascularization of the injured zone [5-8]. For example, recently we have published an article in which we present 3 patients with reduced spinal cord to $70 \%$ and $3 \mathrm{~cm}$ of height (at the C2-C3 level ); $40 \%$ and $2.5 \mathrm{~cm}$ of height (at the T4-T6 level ) and 25\% and $6 \mathrm{~cm}$ of height ( at the T6-T7 level). That is, the 3 patient presented dyscomplete transection and all of them had neurological improvement after omental transplantation [8]. Moreover, recently we have transplanted omental tissue to a 45 -year-old man who presented reduced cervical cord to $30 \%$ and $3 \mathrm{~cm}$ of height at the C4-C5 level. At present, three months after surgery, this patient present some signs of neurological improvement as reduction of spasticity in lower limbs, voluntary movement of the fingers, and burning pain in the penile urethra by Foley catheter (unpublished observation).

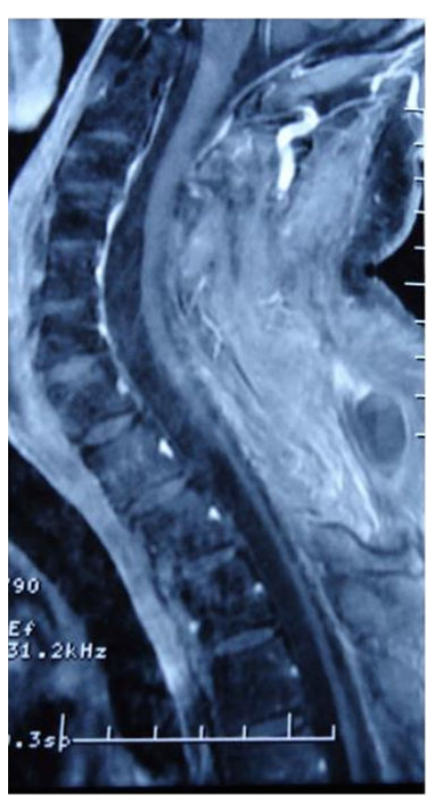

Figure 2: Postoperative T1 MRI with contrast showing severe hypotrophy of the cervical and upper thoracic cord

Our patient reported here confirms that the motor impairment and/or central pain [6,7] both symptoms are indicative of syringomyelia and therefore MRI scans of the spinal cord is indicated for an early diagnosis. Thus, I believe that the first symptoms in this patient were due to syringomyelia located in the lower cervical region and later on, the syrinx extends causing an ascending and descending spinal cord syndrome. Besides this, is very possible that several years later, the syringomyelia was associated with intramedullary ependymoma $[3,9]$.

Moreover, I wish to comment about central pain reported as aching, numbness, burning and tactile hypersensitivity [10,11]. Normally to thalamic and mesencephalic level the neospinothalamic (A-delta fibers) and paleospinothalamic (C-fibers) pathways are separates; while in the spinal cord, both pathways are intermixed [7,10-12]. In the spinal cord, the syringomyelia interrupt to the decussating neospinothalamic pathways by ischemia and thus, it incites central pain by liberation of paleospinothalamic pathways $[6,7,11,12]$. By contrast, clinical evidences suggests that the vascular recanalization by means of aspirin $[13,14]$ or revascularization through omental tissue. Of these, neospinothalamic pathways can cause disappearance of central pain, due to the functional recovery of the A-delta fibers $[3,7,9,11,12]$. Therefore, central pain is a symptom very important in the diagnosis of intramedullary lesions, especially for syringomyelia and/or ependymomas.

Total resection of the ependymoma, when possible, is always recommended as the treatment of choice $[1,2,9]$. Recurrence is rare following complete excision $[15,16]$. In our patient, in the presence of the doubt of a complete excision, the patient received radiotherapy; 
because the tumor resection followed by radiotherapy is considered the most effective treatment for preventing recurrences $[4,15,17]$.

Finally, I think that the intramedullary ependymoma provoked a slow and progressive expansion of the adjacent spinal cord tissue and therefore, an ischemic injury in the intraparenchymal territory of the arterioles originated from the posterolateral and anterior spinal arteries $[6,17,18]$. On the contrary, the tumor resection provoked neurological improvement by recanalization of arterioles in the compressed spinal cord in ischemia and ischemic penumbra and later on, because of neuronal and axonal regeneration. Besides this, our clinical case confirms previous experiences that spinal cord has great tolerance to ischemic lesions and its recovery after decompression and /or revascularization.

In summary, I report to a patient with motor impairment and central pain in the limbs since 17 -years of age and later, at 42 -years, a MRI scans revealed syringobulbia, syringomyelia and cervical ependymoma. Moreover, the patient shows that giant ependymomas can provoke little motor deficits. That is, cervical cord has a large tolerance to ischemic injuries.

\section{References}

1. Chamberlain MC, Tredway TL (2011) Adult primary intradural spinal cord tumors: a review. Curr Neurol Neurosci Rep 11: 320-328.

2. Coxe WS (1961) Tumors of the spinal canal in children. Am Surg 27: 62-73.

3. Hughes JT (1976) Disease of the spine and spinal cord. Greenfield's Neuropathology Chapter 15, London. Edward Arnold 652-686.

4. Schwartz TH, McCormick PC (2000) Intramedullary ependymomas: clinical presentation, surgical treatment strategies and prognosis. Neurooncol 47: 211-218.

5. Rafael H, Malpica A, Ruiz C, Moromizato P, Malo J, et al. (1991) Paraplejia traumática crónica: Diagnóstico y tratamiento. Mundo Médico 18: 11-19.
6. Rafael H, del Angel F (2003) Siringomielia postraumática, dolor central y ependimoma. Rev Per Neurol 9: 20-23.

7. Rafael H, Mego R, Gonzales L, Mostacero H (2000) Trasplante de epiplón para el manejo del dolor crónico intratable. Rev Centro Médico 45: 134-137.

8. Rafael H, Polo G (2015) Neurological improvement after omental transplantation on the upper cervical cord. J Trauma Treat 4: 270.

9. Mancall EL, McCormick PC (1995) Syringomyelia. In, Rowland LP (ed). Merritt's textbook of Neurology. Ninth edition. Baltimore, Williams \& Wilkins 750-753.

10. Pagni CA (1974) Pain due to central nervous system lesions: Physiopathological considerations and therapeutical implications. Adv Neurol 4: 339-349.

11. Boivie J (1996) Central pain. Acta Neurol Scand 94: 6-7.

12. Rafael H (2009) Nervios Craneanos. Tercera edición. Capitulo 7. México, DF. Editorial Prado 119-146.

13. Pawar D, Shahani S, Maroli S (1998) Aspirin---the novel antiplatelet drug. Hong Kong Med J 4: 415-418.

14. Doutremepuich C, Aguejouf O, Desplat V, Duprat D, Eizayaga FX (2012) Thrombotic events associated to aspirin therapy. Thrombosis 2012: 247363.

15. Quigley DG, Farooqi N, Pigott TJ, Findlay GF, Pillay R, et al. (2007) Outcome predictors in the management of spinal cord ependymoma. Eur Spine J 16: 399-404.

16. Joaquim AF, Santos MJ, Tedeschi H (2009) Surgical management of intramedullary spinal ependymomas. Arq Neuropsiquiatr 67: 284-289.

17. Oh MC, Kim JM, Kaur G, Safaee M, Sun MZ, et al. (2013) Prognosis by tumor location in adults with spinal ependymomas. J Neurosurg Spine 18: 226-235.

18. Smith AB, Soderlund KA, Rushing ES, Smirniotopolous JG (2012) Radiologic pathologic correlation of pediatric and adolescent spinal neoplasms: Part1, Intramedullary spinal neoplasms. AJR Am J Roentgenol 198: 34-43. 